\title{
THE BEGINNING OF ISLAM IN CENTRAL ASIA: THE FIRST MOSQUE IN MERV, TURKMENISTAN*
}

\author{
Tirkesh KHODJANIYAZOV, Aydogdy KURBANOV ${ }^{* *}$
}

\begin{abstract}
The first mosque in Central Asia was situated in the center of ancient Merv (Gyaur-kala) in the crossroad of two main streets, starting from four main gates of the town. The mosque was erected in the second half of the $7^{\text {th }}$ century, after the Arab troops conquered Merv. The mosque became known as Beni Makhan Mosque. Using data from medieval sources and topographical works in the 1950s. M. Masson managed to find out the location of the mosque and began excavations, which were completed later in the 1960s by T. Khodjaniyazov. Been built of clay bricks, the first mosque was almost destroyed. The exact design of the mosque of that period is unknown. It was rebuilt in the $11^{\text {th }}-12^{\text {th }}$ centuries, in the time of the Seljuks. The corner minaret, the eastern and partially the southern walls, remained from the old building. The new mosque with three minarets has an incorrect rectangular plan.
\end{abstract}

Keywords: Middle Ages, Mosque, Merv, Turkmenistan, Central Asia.

\section{Orta Asya'da İslam'ın Başlangıcı: Türkmenistan Merv'deki İlk Cami}

Öz: Orta Asya'daki ilk cami, eski Merv'in (Gyaur-kala) merkezinde, şehrin dört ana kapısından başlayarak iki ana caddenin kesiştiği yerde bulunuyordu. Cami, 7. yüzyılın ikinci yarısında, Merv'in Arap birlikleri tarafindan fethedilmesinden sonra inşa edilmiştir. Cami, Beni Makhan Camii olarak tanındı. M. Masson, 1950 'lerde ortaçağ kaynaklarından ve topografik çalışmalardan elde edilen verileri kullanarak caminin yerini bulmayı başardı ve 1960 'larda T. Khodjaniyazov tarafından tamamlanan kazılara başlandı. Kil tuğladan inşa edilen ilk cami, neredeyse yıkılmıştır. O dönemin camisinin kesin tasarımı bilinmemektedir. Selçuklular zamanında, 11-12. yüzyıllarda yeniden inşa edilmiştir. Köşe minaresi, doğu ve kısmen güney duvarları ise daha önceki yapıdan kalmıştır. Üç minareli yeni caminin dikdörtgen planı yanlıştır.

Anahtar kelimeler: Ortaçağ, Cami, Merv, Türkmenistan, Orta Asya.

* Makalenin Geliş ve Kabul Tarihleri:

** Dr. Academy of Sciences of Turkmenistan, Institute of History and Archaeology, Main Research Fellow, Turkmenistan. tirkesh.khodjaniyazov@yandex.ru ORCID: 0000-0003-1640-087X

Dr. Freie Universität Berlin, Institute of Near Eastern Archaeology, Research fellow, Berlin, Germany. aydogdy.kurbanov@fu-berlin.de, ORCID: 0000-0002-1032-7213 


\section{Merv in Medieval Islamic Period}

One of the most famous cities in the territory of Turkmenistan is Merv, near the modern city Bayramali. The origin of this city has its roots in the first half of $1^{\text {st }}$ millennium BC (Khodjaniyazov, Kurbanov and Ovlyakuliyev, 2011, p. 85). Until today, it is possible to watch these magnificent architectural monuments of Merv - the mausoleum of Sultan Ahmad Sanjar, Shahriyar Arc, the mosque Khoja Yusup Khamedani, Mohammad Bin Zeid, and the mausoleum of so-called Ashabs (Companions of the Prophet) - Abu Buraidah al-Aslami and Al-Hakam ibn Amr al-Ghifari. At different periods of history, the Merv oasis was named: Moura - in the sacred book of Zoroastrians Avesta; Margush - in the cuneiform texts of the Achaemenid kings; Margiana - in the Greco-Roman authors' works; Merv - in the sources of Sasanian and Arab periods; Maru - in later Turkmen legends (Khodjaniyazov and Kurbanov, 2011, p. 74). Merv was the oasis centre and the largest city in the East. In size and significance, it was second only to the capitals of major countries in the region. Merv is a group of sites that have been arisen and perished. Various periods of its existence correspond to the sites of Erk-kala (the fortress-citadel), Gyaur-kala, Sultan kala, Abdullakhan-kala and Bayramalihan-kala.

When pursued by the Arabs, the last shahinshah of the Sasanian empire Yazdegerd III (632-651) fled to Khurasan, to the walls of Merv, where he met Nezak Tarkhan, the ruler of Badghis (a region between Serahs and Herat) who came with his troops. According to the medieval author Ahmad al-Baladhuri ( $9^{\text {th }}$ century), between Yazdegerd III and Nezak Tarkhan a conflict flared. The reason was the Nezak Tarkhan's request to give him as wife a daughter of the shahinshah. Yazdegerd III was angered, because he considered the proposal unworthy of his daughter. A considerable role in this quarrel was played by the marzban of Merv Mahuye, who was not honest with his suzerain. As a result, the troops fought, Yazdegerd III was defeated and fled to Merv, but Mahuye did not open the gates of the city for him. The shahinshah was killed not far from Merv and was buried by Christians, who found his body (The History of al-Tabari, 1990, pp. 78-90; Annanepesov, 1992, pp. 9-10).

The cities of Nishapur, TTus, Merv, Abiverd, Nisa, Sarakhs, and Balkh all came under Muslim control. The chronology for these conquests varies but Abu Jafar Muhammad al-Tabari (839-923) dates the above conquests to 651/52 (The History of al-Tabari, 1990, pp. 90-93). Mahuye remained the ruler in Merv, subordinate to the Muslim authorities for at least fifteen years.

Merv, as the capital of the Khurasan during the Umayyad Caliphate (661-750), attracted a large number of settlers from other parts of empire (Kennedy, 1999, p. 29). Arabs built the first mosque and close to it the dar al-imara (administrative house) (Kennedy, 1999, p. 28; Williams, 2018, p. 420). During the Abbasid 
revolution (747-750) which started in Khurasan under the leadership of Abu Muslim al-Khurasani, Merv was taken by his troops in 748 and became the headquarter of pro-Abbasid troops. From Merv, Abu Muslim directed the Abbasid army towards Iran and Iraq, and finally helped by Abu al-Abbas AsSaffah, established in 750 the new empire - the Abbasid Caliphate. Abu Muslim became a governor of Khurasan and shifted the dar al-imara from Gyaur-kala to Sultan-kala, where he built a dome chamber with four iwans. It was situated in the vicinity of the later mausoleum of Sultan Sanjar. As noted by H. Kennedy: "The governor of Khurasan, based in Merv, was one of the most important figures in the caliphate and was almost always chosen from the leading Arab families of the Merv area" (Kennedy, 1999, p. 29).

After the death in 813 of the famous Abbasid caliph Harun al-Rashid in Tus, on his way to Merv, his son Abul Abbas al-Mamun, who was at that time in Merv, was proclaimed as new caliph. He remained in Merv and reigned from here until 819 , then he moved to Baghdad. So, Merv was for six years the temporal capital of the vast Abbasid Caliphate, i.e. Muslim world.

In 820 the Tahirid governors (a founder of the dynasty - Tahir ibn Husain was alMamun's general, helped him during the Abbasid Civil war against his brother Al-Amin) of Khurasan based in Nishapur became de facto autonomous from the Abbasids. Later, in 873 the Saffarids, rulers of Sistan, took Khurasan from the Tahirids. Then, they were pushed back by the Samanids, rulers of Mawarannahr (Transoxiana). From the end of $10^{\text {th }}$ century started in Central Asia the pressure exerted by the Turkic nomads on Khurasan. The Karakhanids (Muslim Turkic rulers) conquered Mawarannahr and destroyed the Samanid state in 999. Khurasan was recovered by a Turkic origin general of the Samanids, Abu Mansur Sebuktegin, who founded a dynasty at Ghazna. But busy conquering India, his successors the Ghaznavids neglected Khurasan and in particular its north-western border. In 1040 after the Dandanakan battle, the Ghaznavids left Khurasan to the Seljuks (from Oghuz tribal confederation). During the Seljuk rule, Merv regained its status of capital (Durand-Guédy, 2015, pp. 3-4). So, Merv reached her highest glory at the time of Great Seljuks, especially during the reign of sultan Ahmad Sanjar (1118-1157). In the Seljuk era $\left(11^{\text {th }}-12^{\text {th }}\right.$ centuries $)$, Merv reaches its highest development. Merv of this period corresponds to the Sultan-kala (Fortress of the Sultan), with an area of 401 hectares, walled by Jalal ad-Din Malik-Shah (1072-1092). Later, during the reign of Sultan Ahmad Sanjar (1118-1157), additional territories were included in the city to the south and north of the settlement by the construction of fortress walls. This is how the northern (with an area of 120 hectares) and southern (with an area of 110 hectares) a circular line of fortifications arose. Thus, the total area of the Seljuk Merv, enclosed by a fortress wall, was 631 hectares, and together with the suburbs, which included in part the territory of the ancient city (fortified settlement Gyaur-kala) - 1500-1800 
hectares. The population reached at least 150 thousand people (Khodjaniyazov, 1990, p. 15). The fortress walls, equipped with semicircular towers protruding outward every 25-30 m, reached a height of 10-12 m and a width of 5.5-6 m., 5 $\mathrm{m}$ of which are a sharp descent to the ditch. The depth of the ditch from the level of the outer platform is $8.2 \mathrm{~m}$, the width is $22 \mathrm{~m}$ (Khodjaniyazov, 1990, p. 18). In size, it is much higher than not only such famous cities in the Middle East as Damascus, Aleppo, Jerusalem, and major cities of Western Europe of the $12^{\text {th }}$ the beginning of the $14^{\text {th }}$ century - Paris, Bologna, Milan, Naples and other cities (Khodjaniyazov and Kurbanov, 2011, pp. 76-77; Khodjaniyazov, Kurbanov and Ovlyakuliyev, 2011, p. 89).

Prospering in Merv were various handicrafts, including textile, pottery, metalworking, jewellery, construction and so on. Particularly impressive was progress reached by Merv potters who devised their own technology and manufactured highly artistic wares - chandelier, nonglazed stamped crockery decorated with zoomorphic, anthropomorphic plots and daintiest ornamentation of vegetation, geometrical and epigraphic motifs (Khodjaniyazov and Kurbanov, 2011, p. 77).

The palace administration was transferred to the new citadel in Shahriyar Ark, which was constructed towards the end of the $11^{\text {th }}$ century (Williams, 2018, p. 422). It is situated in the north-eastern part of the city with the Sultan's palace, government sofas, treasury and barracks. From south to north across the city proceeded channel Majan, provided the city with water by numerous drainage systems, built of baked bricks. In the city centre at the intersection of main street was charsu, where there were major public acts, located near a mosque, a house rule, and in the $40 \mathrm{~s}$ of the $12^{\text {th }}$ century, the ensemble has been included in the Sultan Sanjar mausoleum which is the one of the wonderful creations of medieval architects of Turkmenistan. During this period, Merv had magnificent buildings: mosques, madrasas, libraries, mausoleums, palaces and houses. The high level of culture contributed to the prosperity of scientific thought. In Merv lived and created many outstanding scholars - philosophers, astronomers, physicians, philologists and historians. In the libraries of Merv worked the famous geographer Yakut al-Hamawi (1179-1229), who composed here 'Mujam alBuldan' (The Dictionary of countries). In the sultan Jalal ad-Din Malik-Shah's observatory at Merv, the eminent scientist of East, Omar Khayyam (1048-1131) worked on the most accurate for that time, a solar calendar - 'Jalali calendar'. In other words, Merv was one of the most important cultural centres of Central Asia, created and stored a significant portion of the material and spiritual values of the East. Therefore, in no small measure contributed to the location at the crossroads of the trade caravan routes. Merv was not only a major point of the Silk Road, a place of concentration of foreign merchants, but also formed and sent the trade caravans to different countries. 
In 1153 the Oghuz nomads captured the sultan Sanjar and looted Khurasan. This collapse accelerated the dissolution of the Great Seljuk state. From 1160, Khurasan fell under the control of the Khorezmshahs, epigones of the Seljuks, but in 1220, they were eliminated by the Mongols of Genghis Khan. The intensity of ravages they caused in Merv and in general in Khurasan made irreversible the changes already visible from the second half of the $13^{\text {th }}$ century (Durand-Guédy, 2015, p. 5). Many buildings of Merv were demolished, and until nowadays only few of them survived.

\section{The First Mosque of Central Asia in Historical Sources}

The first mosque in Central Asia was situated in the centre of ancient Merv (Gyaur-kala) in the crossroad of two main streets, beginning from four main gates of the town. The mosque was erected in the second half of the $7^{\text {th }}$ century, after Arab troops conquered Merv by. The mosque became known as Beni Makhan Mosque. The Arabian geographer Shams al-Din Abu Abdallah al-Maqdisi, known as al-Muqaddasi (c. 945/946 - 991) in his work 'Ahsan al-taqasim fi ma' arfat al-aqalim' (The best divisions for knowledge of the regions) mentioned that Merv had a mosque in the middle of old city, which was in the ancient times a cathedral mosque (MITT, 1939, p. 194).

Another Arabic geographer who lived in the $10^{\text {th }}$ century, Abu Ishaq Ibrahim alIstakhri in his work 'Masalik al-Mamalik' (Routes of the Realms), wrote:

She (Merv) has three mosques for cathedral prayers. The first mosque, where the cathedral prayers were offered, was built inside the city (Medina) at the beginning of Islam; when (number) of the Moslems increased, another mosque was built near the city's gate, which was called "old mosque" ... Cathedral prayers in the first mosque were stopped, and now it is known as "Beni Mahan Mosque". Then another mosque was built ...by Abu Muslim (MITT, 1939, p. 172).

On the basis of these data and topographical observations, in 1958 M.E. Masson managed to find out the location of the mosque and began excavations (Masson, 1955 , p. 217), which were completed later by the T. Khojaniyazov (Khodjaniyazov, 1986, pp. 12-14; Khodjaniyazov, 2000, pp. 47-51, 107-111, 161-165; Kurbanov, 2011, pp. 223-225).

\section{Excavation Works}

Built of clay bricks, the first mosque was almost destroyed. It was rebuilt in the $11^{\text {th }}-12^{\text {th }}$ centuries, in the Seljuk period. Just the corner minaret, the eastern and partially the southern walls, which were put into hard cover made of burnt bricks, remained from the old building. The mosque of the $10^{\text {th }}-12^{\text {th }}$ centuries has incorrect rectangle planning which stretched from the northeast to southwest. Its length is $56.5 \mathrm{~m}$, the western part of it, is $36 \mathrm{~m}$ wide, the eastern part where the 
gallery ends, is $30.5 \mathrm{~m}$ wide and in the farthest eastern part where service buildings were situated $23 \mathrm{~m}$.

The excavation works (in 1964), determined that the construction of the outside walls is different: the eastern, western and partially the southern walls are made of clay bricks and both sides are faced with burnt brick (Khodjaniyazov, 1967, p. 33). The northern side including the north-southern corner of the mosque, and part of the southern wall is built of burnt bricks. The northern wall is $2.1 \mathrm{~m}$. thick, it was restored many times and as a result some counterforts appeared. The thickness of the western wall, inside of which a mihrab was included, is $2 \mathrm{~m}$. The thickness of the southern wall is 1,6 m. The mosque had three minarets. The first and the earliest of them was on the south-western corner of the mosque. It was erected from the clay bricks and faced with burnt bricks. It is $5 \mathrm{~m}$. in diameter, the remained height of it is $0.7 \mathrm{~m}$.

The second minaret's diameter is also $5 \mathrm{~m}$. It was situated in the southern facade on the distance of $26.5 \mathrm{~m}$ from the south-western corner of the mosque and $26 \mathrm{~m}$ from the south-eastern corner of the minaret. It was also erected from clay and was faced with burnt bricks. The rectangle stone served as a foundation, which has a size of $7.2 \times 6.2 \mathrm{~m}$. and the height of $1.3 \mathrm{~m}$ and it was made of burnt bricks. The foundation of the third minaret, which just served as a decoration, was fixed in the middle of the northern wall. It is $1,7 \mathrm{~m}$. in diameter, its remained height is $1,5 \mathrm{~m}$. It was made of clay and had the size $29 \times 29 \times 6 \mathrm{~cm} ; 30 \times 30 \times 6 \mathrm{~cm}$ and faced with burnt bricks (Khodjaniyazov, 2000, pp. 47, 107, 161).

In the middle of the building there was a wide yard measure $20.5 \times 19.5 \mathrm{~m}$, in the perimeter of which, the arch galleries were constructed. Those galleries' roofs were dome-shaped and were based on many square and rectangle bearings 1.15 $\mathrm{x} 1.15$ and $1.2 \times 2.2 \mathrm{~m}$ in size. The corners bearings, except the south-eastern one had $\mathrm{T}$ like shape, $2,3 \times 2 \mathrm{~m}$ in size. The south-eastern corner bearing had a round shape $1.1 \mathrm{~m}$ in diameter. They were made of burnt bricks measure $20 \times 20 \times 4$; $22 \times 22 \times 4 ; 23 \times 23 \times 4 \mathrm{~cm}$ in size and remained on the height of $0.5 \mathrm{~m}$. The number of bearings, not including the ones corner, is four in number one each facade. In northern, southern and eastern walls against each bearing pilasters there were pilasters. Their width is $1.15 \mathrm{~m}$. On them the arches are based. So, each side of the yard had 5 arches. The distance between them was from $2.5-3.5 \mathrm{~m}$.

The open yard was covered with burnt bricks 33 x $33 \times 4.5 ; 34$ × 34 x $5 \mathrm{~cm}$ in size. In the edges of the yard bricks were put vertically. The level of the floor in galleries is $0.2 \mathrm{~m}$. higher than the floor in the open yard. The thickness of gallery in the northern part of the facade is $4.6 \mathrm{~m}$., and in the southern $-3.9 \mathrm{~m}$.

The main entrance was situated in the northwest corner of the western facade of the mosque. From both sides of the passage it is marked by identical oval pylons, advanced outside from the line's walls by $1.3 \mathrm{~m}$, erected separately from the wall 
made of the burnt bricks $24 \times 24 \times 4 ; 26 \times 26 \times 6 ; 29 \times 29 \times 4 \mathrm{~cm}$ in size. The width of the passage is $1.6 \mathrm{~m}$. The depth of the entrance including pylons is 2.6 $\mathrm{m}$. The floor is made up of the standard square burnt brick laid in herring-bone pattern. Not far from the first, but in the north-western corner of the northern facade of the mosque the second entrance is situated. The entrance's thickness is $2.4 \mathrm{~m}$ from both sides the great pylons advanced outside on $2.5 \mathrm{~m}$. Both entrances led into a foyer, which was $4.4 \mathrm{x} 4.4 \mathrm{~m}$ in size, and was situated in the northwestern corner of the mosque. In the north-western corner of the building there was a small reservoir in size $1 \times 1.15 \times 0.5 \mathrm{~m}$. It was made of burnt bricks on the hard solution. Its walls and the floor were faced with many-coated waterproof solution. In the distance of $8.5 \mathrm{~m}$ from the front door the third entrance was situated. Probably it was a service entrance with the width of $0.9 \mathrm{~m}$ (Khodjaniyazov, 2000, pp. 50, 110, 164).

To the south from the foyer of the building along the western wall of the mosque between the foyer and mihrab part, there were three small probably service rooms. There were tashnau (sanitary-cleaning construction designed to drain dirty water after washing hands and dishes in a medieval house), suffah, recesses for books, pits which served as a refrigerator, expensive glass dishes, kashin and stamped dishes fragments were found during the excavations. In the mihrab part of the mosque the bearings were laid in two rows. In the second row, which was located between western bearing of the western yard facade and the outside western wall, the alternation of rectangle and round shape bearings were erected. Round shaped bearings $1.05 \mathrm{~m}$ in diameter were erected of the thoroughly polished rectangle and triangle small bricks and rectangle bearings $1.17 \times 2.2 \mathrm{~m}$ in size had not big 3/4 size columns made of burnt bricks on which the arches were based. During the excavations two small columns of this kind were found which had fallen from the north-eastern and south-eastern corners of one of the rectangle bearings. One of these small columns, which remains in its original shape, is made of polished trapezoid bricks and has the height of $2 \mathrm{~m}$ and diameter 0.25 m (Khodjaniyazov, 1967, p. 33).

The upper part of the column ends up by a cornice. The whole trunk of the column is carved. The projecting surface of the column is divided into several levels, which has its own ornaments of definite motive. The motives in general were of vegetable and geometric character. Also, the belt with the inscription of Kufic writing was found. It said: "It is a work of Abul Kasim Muhammad". It is probably the name of the master who made the decoration of mihrab part of the mosque (Khodjaniyazov, 1986, pp. 12-14; Khodjaniyazov, 2000, pp. 50, 110, 164).

Beside it, on the trunk of the column were separate words, written in Kufic writing and concluded into the frame of cartouches. Another small column of the 
same type, which fell from the south-eastern corner of the same bearing remains with the height of $1.5 \mathrm{~m}$ and was also rich in ornaments of different vegetable and geometrical motives, but contained a different inscription. A lot of letter elements of Kufic script cut out of the burnt brick were found in the same part of the mosque. The letters 'aleph', 'lam', 'ra/za', 'sin/shin', 'dal/zal' are distinguished among others. They are $2-2.5 \mathrm{~m}$ in width, traces of alabaster solution have still remained on the rear side of some of them. They apparently fixed the letters to the wall by the alabaster solution and composed the inscriptions. As a whole the mihrab part of the mosque is rich in plaster decorations, the fragments of which with vegetable, geometrical, and epigraphical ornaments in large amounts were found during the excavations.

In the eastern part of the mosque, where the eastern gallery office and household premises were situated, under the floor, at a great depth, a sardoba (water reservoirs) was found. Being built of the different-sized burnt brick, it has a round shape and is $6.6 \mathrm{~m}$ in diameter. The depth down from the floor is $8.1 \mathrm{~m}$. The floor of the sardoba was lined with two rows of burnt brick, crated with three layers of water proof solution and was polished. Vaulted galleries $0.5 \mathrm{~m}, 0.85 \mathrm{~m}$ wide the lower part of which have rectangular hollows $15 \times 12 \mathrm{~cm}$ in size for water-flow approach the reservoir from the western, northern, and south-eastern sides. The stepped vaults are formed by means of gradually growing inside admission of burnt brick. They are connected with the reservoir at a height of $1 \mathrm{~m}$ from the ground, they are connected with some of the numerous canal branches. Two vaulted entrances led inside: the north-western one was $2 \mathrm{~m}$ wide, it led from the mosque's eastern gallery. The southern one, with its stairs laid of burnt brick, start behind the southern outside wall and passing it through at a depth of $6.3 \mathrm{~m}$, and lean against the wall of the sardoba which had a hollow for coming water. The entrance is $1.8 \mathrm{~m}$ wide and $2.8 \mathrm{~m}$ height. It should be noted, that Al-Maqdisi mentioned of such water reservoirs in Merv (MITT, 1939, pp. 203-204).

\section{Conclusion}

Two main periods can be distinguished in the construction and functioning of Beni Mahan Mosque. The original cathedral mosque was built there by the Arabs in the second half of the $7^{\text {th }}$ century, was apparently oriented toward different directions. The exact design of the mosque of that period is not known; it was reoriented towards the qibla during its subsequent reconstruction. The reconstruction was apparently carried out during the reign of the Seljuks in the $11^{\text {th }}-12^{\text {th }}$ centuries. The rich ornamental design of the mosque's interior done in carved figured bricks and carved plaster dates to the same period.

The decoration of public buildings and dwellings by carved gunch was widely used and was one of the elements of so-called Seljuk style in art. It was also used in the regions of southern Turkmenistan, including the Merv oasis. Carved plaster 
of the Dandanakan Mosque of the $11^{\text {th }}$ century is considered to be a genuine masterpiece of medieval applied arts (Zakhoder, 1943, pp. 74-77; Yershov, 1947, pp. 126-136). Carved plaster was widely used in decorating the Sultan Sanjar (12 ${ }^{\text {th }}$ century) (Pugachenkova, 1958, p. 325) and Abu Buraidah al-Aslami $\left(11^{\text {th }}\right.$ century) mausoleums. Ornamental panels with ganch (a mixture of gypsum and clay) carving were found by archaeologists during the excavations of rich dwelling houses of the Seljuk nobility in Merv (Lunina, 1980, pp. 59-84). Thanks to the wide practice of epigraphical ornamental motives in ganch carving, we know some of the names of distinguished carvers of that time, Abu Bakr (Pugachenkova, 1958, p. 258), and Abul Kasim Muhammed (Khodjaniyazov, 1967, p. 33).

Burnt brick with the size of $19-28.5 \mathrm{~cm}$ in length and $3-5 \mathrm{~cm}$ in width was widely used in the mosque construction during that period. The architectural monuments of Turkmenistan and Central Asia of $11^{\text {th }}-12^{\text {th }}$ centuries mausoleums of Abul Fazl (Sarakhs-Baba), of Abu Said Abul Khayr (Meana-Baba), of Alamberdar, Caravanserai of Daya-Khatyn (Pribytkova, 1955, pp. 39-76), Muhammed ibn Zaid and Sultan Sanjar Mausoleums (Pilyavskiy, 1950, p. 116), and a New Nisa bath-house (Pugachenkova, 1958, p. 242) present this standard of bricks. The brick of the same standard was used in constructions of that time in the piedmont area of the Kopetdag Mountains (Litvinskiy, 1953, p. 263), ShirKabir Mosque (Grazhdankina, 1958, p. 36) and also in architectural edifices of Khorezm (Voronina, 1951, p. 93). Another argument for such dating is the existence of kashin and stamped ceramics, characteristic for the $11^{\text {th }}-12^{\text {th }}$ centuries, among the archaeological materials found in Merv (Lunina, 1962, pp. 217-418).

The mosque was partially destroyed after the rapid growth of Merv in the times of the Great Seljuk Empire (1038-1157). As a result, a part of it was abandoned and enclosed. This is apparently connected with the weakening of the position of Merv in connection with the fall of the Seljuk rule and its change into a provincial city as a constituent of the state of Khorezmshahs. A narrow passage of $0.9 \mathrm{~m}$ in width was cut through the southern wall between two minarets during this period. After the complete desolation of the mosque which apparently happened after the devastation of Merv by the Mongols, the adjoining territory became a cemetery as it was "the sacred place". Many burials of sagana type along the southern and western external walls of the mosque were cleared. So, the chronological outline of inhabitancy in the mosque with some intervals can be determined within the second half of the $7^{\text {th }}$ century - beginning of the $13^{\text {th }}$ century. 


\section{Bibliography}

Annanepesov, M. A. (1992). Voyny Islama: Materialy po Istorii Turkmen $i$ Turkmenistana. Ashkhabad.

Durand-Guédy, D. (2015). Pre-Mongol Khurasan. A Historical Introduction. In R. Rante (Ed.), Greater Khurasan. History, Geography, Archaeology and Material Culture (pp. 1-7). Göttingen: De Gruyter.

Grazhdankina, N.S. (1958). Drevniye Stroitel'nyye Materialy Turkmenii. In M.E. Masson (Ed.), Trudy Yuzhno-Turkmenistanskoy Arkheologicheskoy Kompleksnoy Ekspeditsii VIII (pp. 11-217). Ashkhabad.

Kennedy, H. (1999). Medieval Merv: an Historical Overview. In G. Herrmann (Ed.), Monuments of Merv. Traditional Buildings of the Karakum (pp. 27-44). London.

Khodjaniyazov, T. (1967). Reznaya Kolonna Pervoy Arabskoy Sobornoy Mecheti. Pamyatniki Turkmenistana, 4, 33.

Khodjaniyazov, T. (1986). Zagadochnoye Podzemnoye Sooruzheniye v Starom Merve. Pamyatniki Turkmenistana, 1, 12-14.

Khodjaniyazov, T. (1990). Raskopki Ob'yektov Sel'dzhukskoy Epokhi v Starom Merve. Merv v Drevney i Srednevekovoy Istorii Vostoka. Тезисы докладов научного симпозиума. Ashkhabad, 15-18.

Khodjaniyazov, T. (2000). Pervaya Sobornaya Mechet' Merva. Miras, 1, 47-51, 107-111, 161-165.

Khodjaniyazov, T. and Kurbanov, A. (2011). Turkmenistan. In K. Baipakov and Sh. Pidayev (Eds.), Prominent Archaeological Sites of Central Asia on the Great Silk Road (pp. 70-85). Samarkand.

Khodjaniyazov, T., Kurbanov, A. and Ovlyakuliyev, M. (2011). Velikiy Shelkovyy put' $i$ Turkmenistan. Ashgabat.

Kurbanov, A. (2011). Pervaya Musul'manskaya Mechet' v Tsentral'noy Azii. In Drevnyaya Material'naya Kul'tura Turkmenistana $i$ Yeye Mesto $v$ Razvitii Mirovoy Tsivilizatsii (pp. 223-225). Ashgabat.

Litvinskiy, B.A. (1953). Otchet o Rabote Arkheologicheskoy Gruppy V Otryada YUTAKE v 1947 g. (Rekognostsirovka Rayona Bezmein - Kizyl-Arvat). In M. E. Masson (Ed.), Trudy Yuzhno-Turkmenistanskoy Arkheologicheskoy Kompleksnoy Ekspeditsii, II (pp. 253-314). Ashkhabad.

Lunina, S.B. (1962). Goncharnoye Proizvodstvo v Merve X - Nachala XIII vv. In M. E. Masson (Ed.). Trudy Yuzhno-Turkmenistanskoy Arkheologicheskoy Kompleksnoy Ekspeditsii, XI (pp. 217-418). Ashkhabad.

Lunina, S.B. (1980). Izucheniye Zhilykh Domov Merva X - Nachala XIII vv. In M.E. Masson (Ed.), Trudy Yuzhno-Turkmenistanskoy Arkheologicheskoy Kompleksnoy Ekspeditsii, XVII (pp. 59-84). Ashkhabad.

Masson, M. Ye. (1955). Kratkaya Khronika Polevykh Rabot YUTAKE za 1948-1952 gg. In M. E. Masson (Ed.), Trudy Yuzhno-Turkmenistanskoy Arkheologicheskoy Kompleksnoy Ekspeditsii, V (pp. 197-249). Ashkhabad.

Materialy po Istorii Turkmen i Turkmenii (MITT). Tom 1. (1939). Moskva, Leningrad. 
Pilyavskiy, V. I. (1950). Arkhitektura Drevnego Merva. Nauchnyye Trudy Leningradskogo Inzhenerno-Stroitel'nogo Instituta, 10, 95-122.

Pribytkova, A. M. (1955). Pamyatniki arkhitektury XI v. v Turkmenii. Moskva.

Pugachenkova, G. A. (1958). Puti Razvitiya Arkhitektury Yuzhnogo Turkmenistana Pory Rabovladeniya i Feodalizma. M. E. Masson (Ed.), Trudy YuzhnoTurkmenistanskoy Arkheologicheskoy Kompleksnoy Ekspeditsii, VI. Moskva.

Pugachenkova, G. A. (1967). Iskusstvo Turkmenistana. Moskva.

The History of al-Tabari (Vol. XV) (R. S. Humphreys, Trans.). (1990). Albany, N.Y.

Voronina, V.L. (1951). Stroitel'naya Tekhnika Drevnego Khorezma. Trudy Khorezmskoy Arkheologo-Etnograficheskoy Ekspeditsii, 1, 87-104.

Williams, T. (2018). Sultan Kala: The Development of a City. In R. Muradov (Ed.), Traces of Empires. Culture of Central Asia from Alexander the Great to the Timurids (pp. 415-430). Kabul, Bishkek.

Yershov, S.A. (1947). Dandenakan (Arkheologicheskiye Razvedki u Tash-Rabata v 1942 g.). In Kratkiye Soobshcheniya Instituta Istorii Material'noy Kul'tury, XV (pp. 126-136).

Zakhoder, B.N. (1943). Dendanekan. Istoricheskiy Zhurnal, 3-4, 74-77. 


\section{Figures}

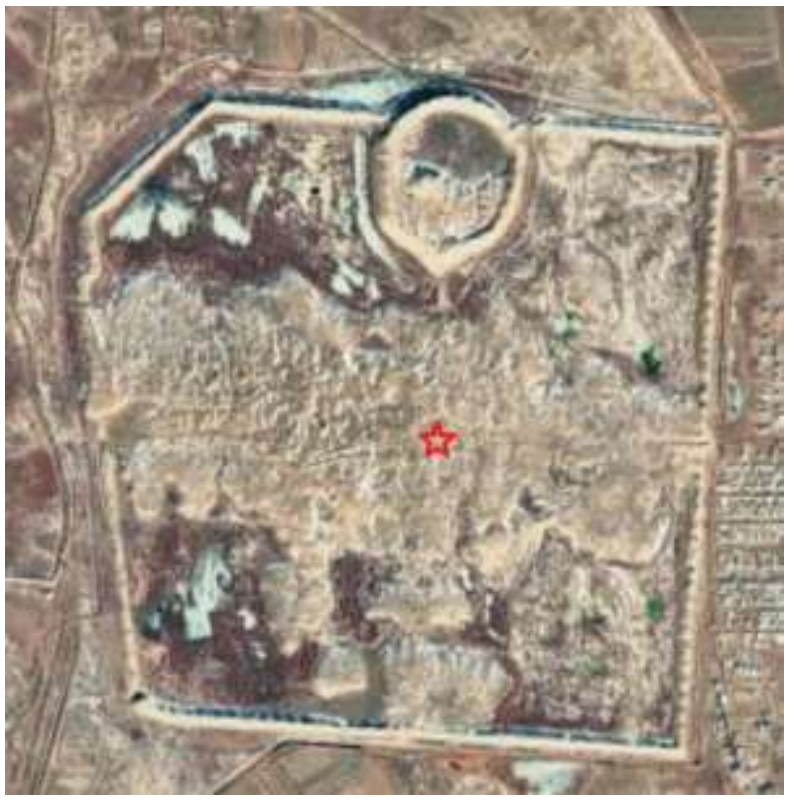

Figure 1. Plan of Merv (Gyaur-kala) with Beni Mahan mosque place indication (derived from Google Earth map)

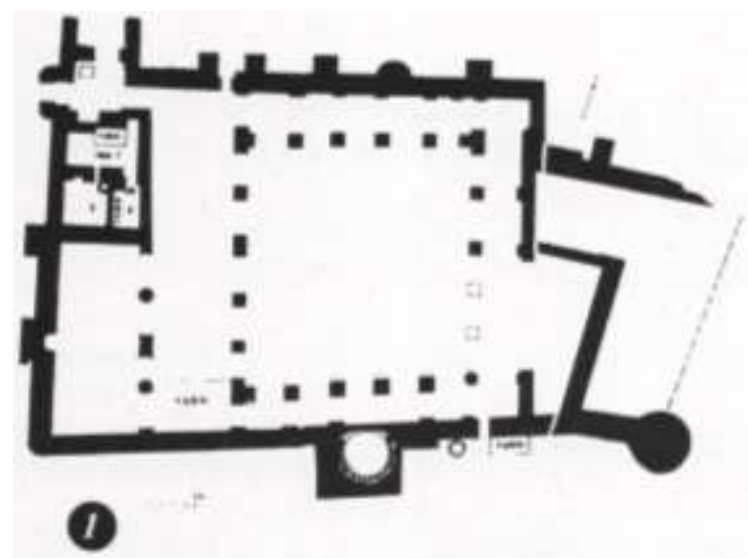

Figure 2. Plan of the mosque (after T. Khodjaniyazov) 


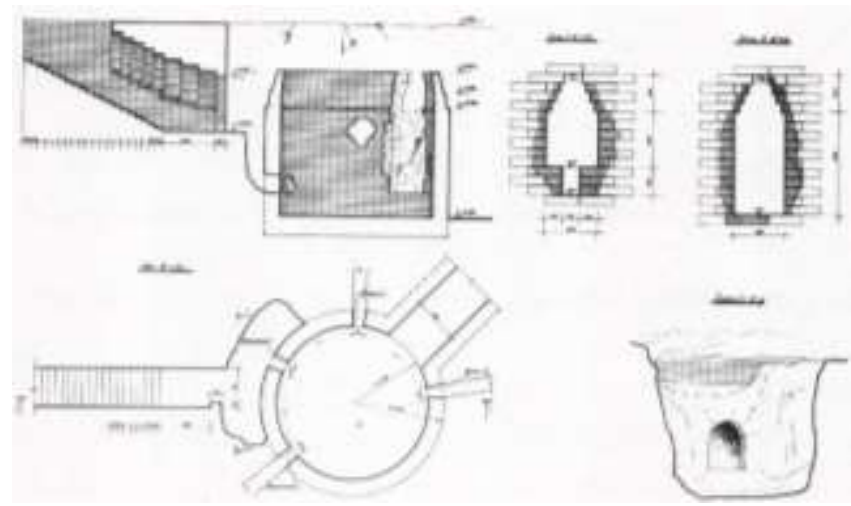

Figure 3. Plan and sections of sardoba (underground water reservoir) (after T. Khodjaniyazov)

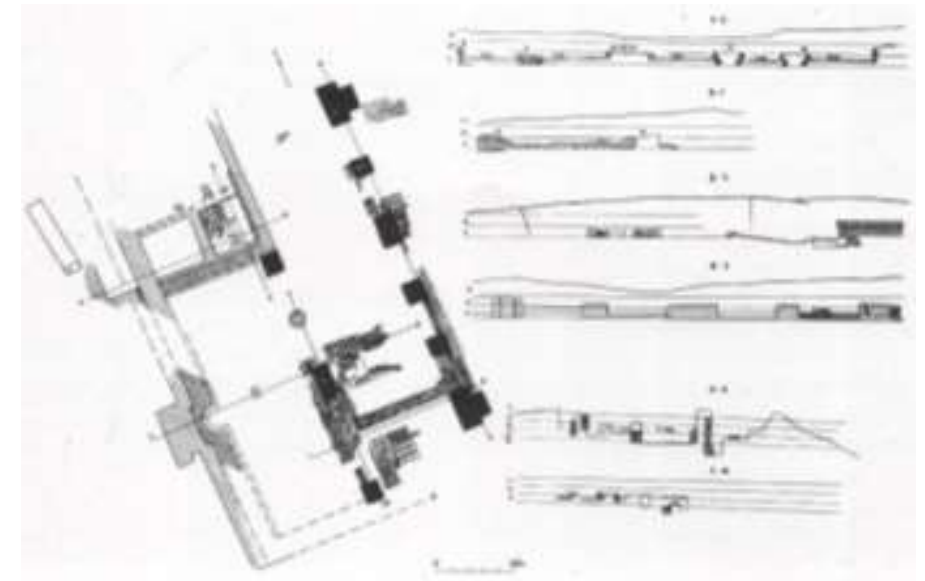

Figure 4. Plan and sections of the mihrab part of the mosque (after T. Khodjaniyazov) 


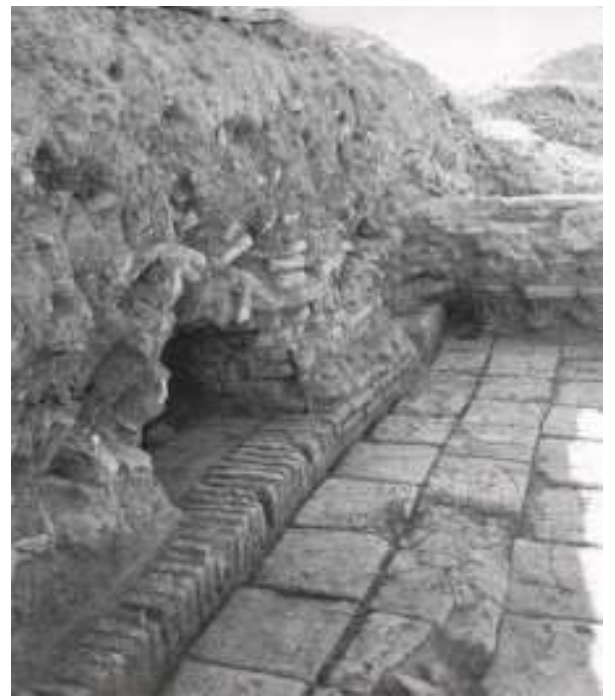

Figure 5. The open yard of the mosque (photo courtesy of T. Khodjaniyazov)

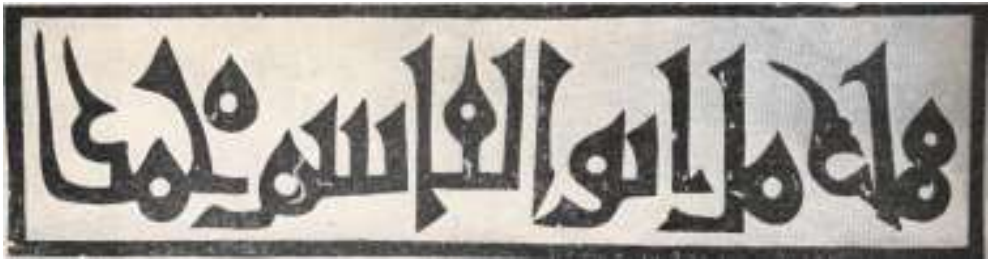

Figure 6. Inscription on the column (after of T. Khodjaniyazov)

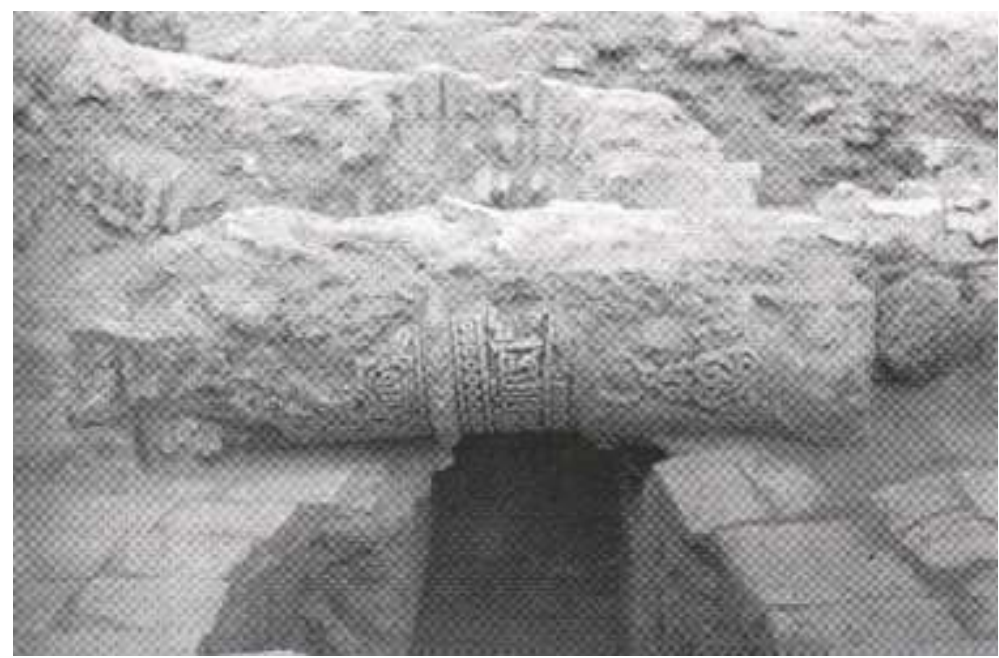

Figure 7. Carved column (photo courtesy of T. Khodjaniyazov) 


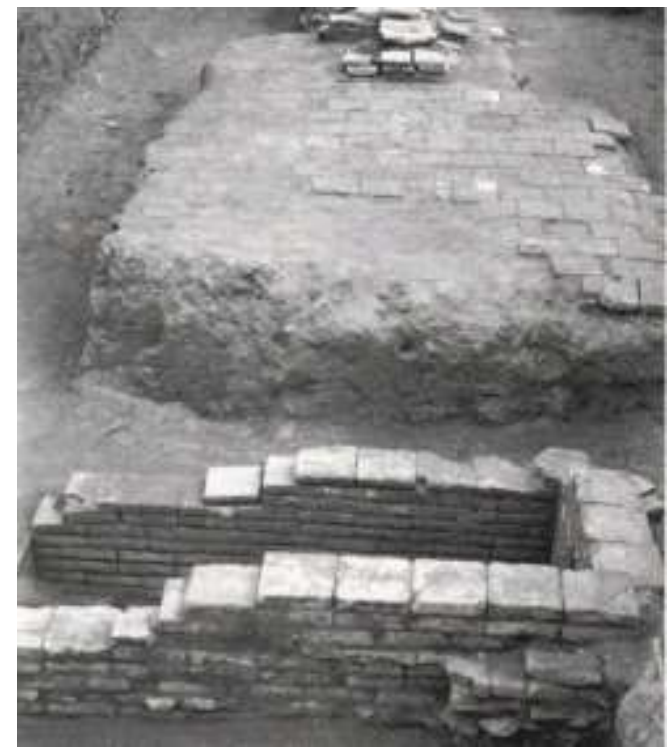

Figure 8. Sagana type burial (photo courtesy of T. Khodjaniyazov)

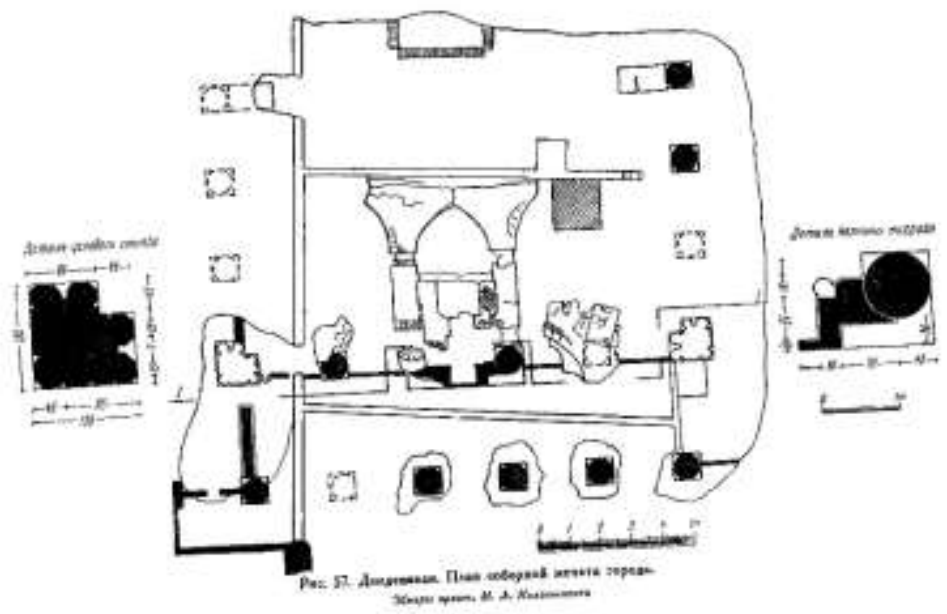

Figure 9. Dandanakan. Plan of cathedral mosque (after Yershov, 1947, p. 131) 
